\title{
Contemporary Issues of Climate Change on Oil and Gas Industry Operations
}

\author{
Oyeleke O. Oyerinde \\ Department of Environmental Management and Toxicology, Federal University of Petroleum Resources \\ Effurun, Delta State. Nigeria. \\ * Corresponding author email: oyerinde.oyeleke@fupre.edu.ng
}

Received: 1 April 2018 / Revised: 26 May 2018 / Accepted: 1 June 2018 / Published: 03 June 2018

\begin{abstract}
The reality of climate change as an aspect of broader global and environmental change attributable to either natural or anthropogenic cause is becoming more evident. Equally, energy, chiefly oil and gas is not only a major climate change inducer via greenhouse gas emissions anymore, but also a victim of the impacts therein. As such, this paper examines the impact of recorded changes in climatic variables on oil and gas operations categorized into upstream, midstream and downstream operations representing exploration and production, transportation, along with processing and distribution respectively. Identified changes in weather events primarily driven by general climate change having significant impact on oil and gas operations and infrastructure include increasing temperature, increasing flooding, storm surges, sea level rise, coastal erosion, intense winds and waves, drought/water shortage and subsidence/landslides/mudslides and they all pose tremendous risk to onshore and offshore (shallow and deep water) operations and installations. Several adaptation measures are currently being implemented some of which are already yielding positive results. Adaptation measures are being complemented with mitigation strategies as long-term solutions. Sadly, most developing oil producing countries are still way behind in adopting various existing adaptation measures and implementing mitigative strategies due to prevalent low capacity.
\end{abstract}

Keywords: adaptation, climate change, downstream, midstream, mitigation, oil and gas, upstream

\section{Introduction}

In recent times, there has been a strong consensus within the scientific community about the reality of global change. Global change has been attributed to interactions between natural vagaries in the earth's abiotic and biotic composition and the wider effects of human activity [1]. Therefore, global change comprises of both natural and man-made components mainly driven by human population changes and economic development. Historically, global change has been driven by sunspot disparity, plate tectonics, volcanism, resource exhaustion, propagation and diminution of life, Earth's eccentricity and obliquity. In recent times, an integral aspect of a broader global change is climate change which has been attributed to widespread loss of biodiversity, specie collapse, desertification, ocean

acidification, ozone depletion, pollution, and other broad scale changes [2], [3]. Apart from climate, changes witnessed in supply and demand of energy over the years - generally referred to as energy transition - have brought about significant changes globally. Right from invention of steam engine about 300 years ago driving industrial economies with coal as the primary fuel to the 21st century when many economies underwent transformations in the fuels and conversion technologies employed to meet emerging demands through the use of fossil fuels chiefly petroleum oil and natural gas [4]. Against this background, this analysis examines the link between two fundamental aspects of global change; climate change and oil and gas industry operations with the aim of revealing the impact 
of changing climate on upstream, midstream and downstream sectors of the petroleum industry.

\subsection{Climate Change}

"Climate change is a change in the state of the climate that can be identified (e.g. using statistical tests) by changes in the mean and/or the variability of its properties and that persists for an extended period, typically decades or longer" [5] [6]. Usually, emphasis is on the level of shift from the average and its effect on the environment [7]. It's worth mentioning that some climate scientists believe that temporary disparities in climate between 100 to 150 years may not be eligible to be referred to as climate change, rather, climate change is permanent in nature taking a minimum of 150 years with evident and permanent influence on the environment [8].

\subsubsection{Evidence of Climate Change}

The evidences of climate change are diverse and compelling. Some of these are summarized in table 1 . Table 1 is not only depict evidences of climate change, it also shows the link - as propounded by the anthropogenic global warming theory - between increased GHG concentration in the atmosphere and change in temperature which subsequently influences loss of ice sheets, rise in sea level and warming of oceans.

\subsubsection{Causes of Climate Change}

The Earth's climate has changed over the centuries and millennia due to a number of different factors which can be surmised into two broad categories namely; natural processes (biogeographical) and human activities (anthropogenic) [7]. Biogeographical Factors/Natural Processes can be further subdivided into astronomical and extraterrestrial factors. Astronomical Factors include changes in the earth's orbit eccentricity, changes in the plane of earth's obliquity, changes in orbital procession, shifting of the earth on its polar axis hypothesis or polar wandering and asteroid collision [11] [13]. Extra-terrestrial factor pertains to solar radiation variability, that is, changes in the brightness of the sun [11].

Anthropogenic processes on the other hand refers to induced climate change which involves human actions that either release huge amount of GHGs into the atmosphere or activities that reduce the amount of $\mathrm{CO}_{2}$ taken in from the atmosphere [14]. Sources of large quantities of GHG emissions include industrialization, burning of fossil fuel, gas flaring, urbanization and agriculture. Conversely, human actions that decrease the quantity of carbon sinks are deforestation, land use change, water pollution and agricultural activities [5].

Table 1: Climate Change and Perceived Implications [7] [9] [10]

\begin{tabular}{|c|c|c|}
\hline \multicolumn{2}{|r|}{ Climatic Features } & Implications of Change \\
\hline \multirow{2}{*}{ 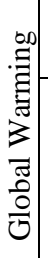 } & $\begin{array}{l}\text { Greenhouse Gas } \\
\text { Concentration }\end{array}$ & $\begin{array}{l}\text { Emission of Green House Gases }(\mathrm{GHG}) \text { thorough industrialization, transportation etc. is raising the GHG intensity } \\
\text { in the lower atmosphere. Current } \mathrm{CO}_{2} \text { concentration is about } 393 \mathrm{ppm} \text {, highest in in the past six and a half centuries. }\end{array}$ \\
\hline & $\begin{array}{l}\text { Change in Global } \\
\text { Temperature }\end{array}$ & $\begin{array}{l}\text { Earth's temperature has increased since } 1880 \text { mostly attributable to increasing concentration of GHG. Most of this } \\
\text { temperature increase happened since the } 1970 \text { s, with the twenty hottest years happening since } 1981 \text { and all ten of } \\
\text { the hottest years experienced between } 1996 \text { and } 2012 \text {. Global temperature has risen by about } 0.566^{\circ} \mathrm{C} \text { to } 0.92^{\circ} \mathrm{C} \\
\text { since } 1860 \text {. }\end{array}$ \\
\hline \multicolumn{2}{|c|}{$\begin{array}{l}\text { Ozone Layer } \\
\text { Depletion }\end{array}$} & $\begin{array}{l}\text { Since the late } 1970 \mathrm{~s} \text {, it is estimated that there is a gradual decline, around } 4 \% \text { every } 10 \text { years in the total volume } \\
\text { of ozone in Earth's ozone layer which may pose health risk such as various cancers, extreme weather events like } \\
\text { drought and desertification due to destruction of the layer protecting us from Sun's dangerous rays. }\end{array}$ \\
\hline \multicolumn{2}{|c|}{ Shrinking ice sheets } & $\begin{array}{l}\text { Greenland ice sheet cover receded between } 150 \mathrm{~km}^{3} \text { and } 250 \mathrm{~km}^{3} \text { every year between } 2002 \text { and } 2006 \text {. In the } \\
\text { Antarctica, around } 152 \mathrm{~km}^{3} \text { of ice vanished between } 2002 \text { and } 2005\end{array}$ \\
\hline \multicolumn{2}{|c|}{ Sea Level Rise } & $\begin{array}{l}\text { From effect of shrinking/melting ice sheets, global sea level rose about } 17 \mathrm{~cm} \text { in the last } 100 \text { years. This has caused } \\
\text { inundation of several Islands, low-lying delta areas, sacking dwellers of such locations. }\end{array}$ \\
\hline \multicolumn{2}{|r|}{ Ocean Acidification } & $\begin{array}{l}\mathrm{CO}_{2} \text { content of the Earth's oceans has been increasing since } 1750 \text {. Presently, it is rising about } 2 \text { billion tons per } \\
\text { annum leading to increase in ocean acidity by around } 30 \% \text {. }\end{array}$ \\
\hline \multicolumn{2}{|c|}{ Warming Oceans } & $\begin{array}{l}\text { Surface } 700 \mathrm{~m} \text { of the ocean has warmed between } 0.16^{\circ} \mathrm{C}-0.302^{\circ} \mathrm{C} \text { since } 1969 \text { via absorbed grown heat of the } \\
\text { atmosphere. This may cause changes/damage to the ocean habitat. }\end{array}$ \\
\hline
\end{tabular}


Oyeleke O. Oyerinde, Int. Ann. Sci.; Vol. 5, Issue 1, pp: 33-46, 2018

The various climate change proofs have been linked to expansion of the greenhouse effect - a process by which long wave radiation from the earth surface derived from short waves from the sun, are absorbed by atmospheric greenhouse gasses such as carbon dioxide, methane, water vapor, nitrous oxide, ozone etc. and re-radiated back to the lower atmosphere [3] - traced to increased levels of GHG in the atmosphere. IPCC climate change models demonstrates continued change at a range of possible emission scenarios throughout the current century. It is believed that sustained rise at present rate bring about global mean temperature rise of $2.6-4.8^{\circ} \mathrm{C}$ and sea level rise of $0.45-0.82$ meters compared to pre-industrial heights [15] [16].

In most developing countries, for instance in Nigeria, adaptive capacity is generally low due to low level of technology, widespread low income and generally poor standard of living thereby intensifying the degree of vulnerability. Several empirical studies conducted in the country show that there has been a rise in temperature by $1.9^{\circ} \mathrm{C}$ since 1860 and a decrease in rainfall by $91 \mathrm{~mm}$ [7] which partly explains the southward movement of desert encroachment [17], [18] in the country.

\subsection{Oil and Gas Industry}

Various economic models point to the fact that there is a positive relationship between economic development and intensity of energy demand and consumption. The large proportion of global energy requirement met by fossil fuels is comprised mainly of petroleum oil and gas. Its discovery has made several nations wealthy thereby driving aggressive exploration activities in several nations with potentials. Today, with increasing discoveries primarily due to improved technologies, many countries now belong to the "Oil Producing Countries" and have benefited immensely from the revenue derived therein, but not without attendant environmental consequences.

Table 2 shows that global crude oil reserve stands at 1.7 trillion barrels [19] out of which Venezuela has the highest proved volume of over 300 $(17.6 \%)$ billion barrels while the Middle East countries jointly account for about $48 \%$ of the global figure. In terms of production, global output is estimated around 92.15 million $\mathrm{bbl} / \mathrm{d}$ with USA and Saudi Arabia accounting for 13.4\% each (over 12.3 million bbl/d) while the Middle East also record the largest regional output share of $34.5 \%$.

Natural gas reserve on the other hand is estimated at 186.6 trillion $\mathrm{m}^{3}$, out this figure, Middle East region represents 42.5\% while Europe and Eurasia accounts for 30.4\%. Production wise, USA leads the pack with $21.1 \%$ (higher than all other region aggregates except Middile East with 28.2\%) of the global volume of 3551.6 billion $\mathrm{m}^{3}$ followed by Russia with 16.3\% (same as the entire Asia Pacific [19].

There are about 34 oil producing countries in Africa [20]. In terms of gas, Algeria, Egypt, Equatorial Guinea, Libya, Mozambique and Nigeria are net exporters while other producing countries include Angola, Cameroon, Congo, Cote d'Ivoire, Gabon, Morocco, Senegal, South Africa, and Tanzania.

Africa's share of world crude oil reserves currently is about $7.5 \%$. Most of the oil reserves in Africa are located in Libya, Nigeria, Algeria, Angola, and Sudan, with combined share of more than 90 percent of the continent's reserves. Libya and Nigeria own 2.8 and 2.2 percent, respectively, of global reserves [21]. As at end of 2016, Africa's proved crude oil reserve stood at 128 billion barrels. Per natural gas, Africa aggregate reserve is estimated to be 14.3 trillion (7.6\% of global volume) cubic meters with Nigeria and Algeria accounting for almost $70 \%$ of the total volume [19].

Nigeria is the highest producer of crude oil in Africa and thirteenth in the world with an average output of about $1.9-2.4$ million barrels per day. It is also having the second largest proven reserve after Libya estimated at 37 billion barrels. Its gas reserve is estimated at 5.3 trillion cubic meters representing $2.8 \%$ of the world figure is the highest in Africa while production currently stands at 45 billion cubic meters representing about $1.3 \%$ of world total production [19]. In Nigeria, Oil and gas accounts for more than $90 \%$ foreign exchange earnings, about $65 \%$ government budgetary revenue and more than $15 \%$ of the country's gross domestic product. The country has a total of 393 oil blocks out of 
Contemporary Issues of Climate Change on Oil and Gas Industry Operations

which 185 are active comprising of 69 oil rigs.

The total number of oils wells in 2015 stood at
113 with five refineries and one liquefied natural gas plant [22].

Table 2: Oil and Natural Gas Proved Reserves, Production and Consumption (2016) [19]

\begin{tabular}{|c|c|c|c|c|c|c|c|c|}
\hline \multirow[t]{3}{*}{ Country/Region } & \multicolumn{4}{|c|}{ Oil } & \multicolumn{4}{|c|}{ Gas } \\
\hline & \multicolumn{2}{|l|}{ Reserve } & \multicolumn{2}{|l|}{ Production } & \multicolumn{2}{|l|}{ Reserve } & \multicolumn{2}{|c|}{ Production } \\
\hline & $\begin{array}{l}\text { Quantity } \\
\text { (thousand } \\
\text { million } \\
\text { barrels) } \\
\end{array}$ & $\begin{array}{l}\text { Share of } \\
\text { Total }\end{array}$ & $\begin{array}{l}\text { Quantity } \\
\text { (thousand } \\
\text { barrels } \\
\text { daily) }\end{array}$ & $\begin{array}{l}\text { Share of } \\
\text { Total }\end{array}$ & $\begin{array}{l}\text { Quantity } \\
\text { (trillion } \\
\text { cubic } \\
\text { meters) } \\
\end{array}$ & $\begin{array}{l}\text { Share of } \\
\text { Total }\end{array}$ & $\begin{array}{l}\text { Quantity } \\
\text { (billion } \\
\text { cubic } \\
\text { meters) }\end{array}$ & $\begin{array}{l}\text { Share of } \\
\text { Total }\end{array}$ \\
\hline US & 48.0 & $2.8 \%$ & 12354 & $13.4 \%$ & 8.7 & $4.7 \%$ & 749.2 & $21.1 \%$ \\
\hline Canada & 171.5 & $10.0 \%$ & 4460 & $4.8 \%$ & 2.2 & $1.2 \%$ & 152.0 & $4.3 \%$ \\
\hline Mexico & 8.0 & $0.5 \%$ & 2456 & $2.7 \%$ & 0.2 & $0.1 \%$ & 47.2 & $1.3 \%$ \\
\hline Total North America & 227.5 & $13.3 \%$ & 19270 & $20.9 \%$ & 11.1 & $6.0 \%$ & 948.4 & $26.7 \%$ \\
\hline Brazil (*Argentina) & 12.6 & $0.7 \%$ & 2605 & $2.8 \%$ & 0.4 & $0.2 \%$ & $* 38.3$ & $* 1.1 \%$ \\
\hline $\begin{array}{l}\text { Ecuador } \\
(* \text { Colombia) }(\wedge \text { Peru }) \\
(\sim \text { Trinidad } \quad \& \\
\text { Tobago })\end{array}$ & 8.0 & $0.5 \%$ & $* 924$ & $* 1.0 \%$ & $\wedge^{\wedge} 0.4$ & ${ }^{\wedge} 0.2 \%$ & -34.5 & $\sim 1.0 \%$ \\
\hline Venezuela & 300.9 & $17.6 \%$ & 2410 & $2.6 \%$ & 5.7 & $3.1 \%$ & 34.3 & $1.0 \%$ \\
\hline $\begin{array}{l}\text { Other S. \& Cent. } \\
\text { America }\end{array}$ & 6.4 & $0.4 \%$ & 1535 & $1.7 \%$ & 1.1 & $0.6 \%$ & 56.0 & $1.9 \%$ \\
\hline $\begin{array}{l}\text { Total S. \& Cent. } \\
\text { America }\end{array}$ & 327.9 & $19.2 \%$ & 7474 & $8.1 \%$ & 7.6 & $4.1 \%$ & 177.0 & $5.0 \%$ \\
\hline $\begin{array}{l}\text { Kazakhstan } \\
\text { (*Turkmenistan) }\end{array}$ & 30.0 & $1.8 \%$ & 1672 & $1.8 \%$ & $* 17.5$ & $* 9.4 \%$ & $* 66.8$ & $* 1.9 \%$ \\
\hline Norway & 7.6 & $0.4 \%$ & 1995 & $2.2 \%$ & 1.8 & $0.9 \%$ & 116.6 & $3.3 \%$ \\
\hline Russian Federation & 109.5 & $6.4 \%$ & 11227 & $12.2 \%$ & 32.3 & $17.3 \%$ & 579.4 & $16.3 \%$ \\
\hline $\begin{array}{l}\text { Other Europe \& } \\
\text { Eurasia }\end{array}$ & 14.4 & $0.9 \%$ & 2823 & $3.0 \%$ & 5.2 & $2.8 \%$ & 237.3 & $6.7 \%$ \\
\hline $\begin{array}{l}\text { Total Europe \& } \\
\text { Eurasia }\end{array}$ & 161.5 & $9.5 \%$ & 17716 & $19.2 \%$ & 56.7 & $30.4 \%$ & 1000.1 & $28.2 \%$ \\
\hline Iran & 158.4 & $9.3 \%$ & 4600 & $5.0 \%$ & 33.5 & $18.0 \%$ & 202.4 & $5.7 \%$ \\
\hline Iraq (*Qatar) & 153.0 & $9.0 \%$ & 4465 & $4.8 \%$ & $* 24.3$ & $* 13.0 \%$ & $* 181.2$ & $* 5.1 \%$ \\
\hline Saudi Arabia & 266.5 & $15.6 \%$ & 12349 & $13.4 \%$ & 8.4 & $4.5 \%$ & 109.4 & $3.1 \%$ \\
\hline Other Middle East & 235.6 & $13.8 \%$ & 10374 & $11.3 \%$ & 13.2 & $7.0 \%$ & 144.7 & $4.1 \%$ \\
\hline Total Middle East & 813.5 & $47.7 \%$ & 31789 & $34.5 \%$ & 79.4 & $42.5 \%$ & 637.8 & $18.0 \%$ \\
\hline Algeria & 12.2 & $0.7 \%$ & 1579 & $1.7 \%$ & 4.5 & $2.4 \%$ & 91.3 & $2.6 \%$ \\
\hline $\begin{array}{ll}\text { Libya } & \left({ }^{*} \text { Angola }\right) \\
\left({ }^{\wedge} \text { Egypt }\right) & \end{array}$ & 48.4 & $2.8 \%$ & $* 1807$ & $* 2.0 \%$ & $\wedge 1.8$ & $\wedge 1.0 \%$ & $\wedge 41.8$ & $\wedge 1.2 \%$ \\
\hline Nigeria & 37.1 & $2.2 \%$ & 2053 & $2.2 \%$ & 5.3 & $2.8 \%$ & 44.9 & $1.3 \%$ \\
\hline Other Africa & 30.3 & $1.8 \%$ & 2335 & $2.5 \%$ & 2.6 & $1.4 \%$ & 30.3 & $0.8 \%$ \\
\hline Total Africa & 128.0 & $7.5 \%$ & 7892 & $8.6 \%$ & 14.3 & $7.6 \%$ & 208.3 & $5.9 \%$ \\
\hline China & 25.7 & $1.5 \%$ & 3999 & $4.3 \%$ & 5.4 & $2.9 \%$ & 138.4 & $3.9 \%$ \\
\hline India (*Australia) & 4.7 & $0.3 \%$ & 856 & $0.9 \%$ & $* 3.5$ & $* 1.9 \%$ & *91.2 & $* 2.6 \%$ \\
\hline $\begin{array}{l}\text { Vietnam } \\
(* \text { Indonesia) } \\
(\wedge \text { Malaysia) } \\
\end{array}$ & 4.4 & $0.3 \%$ & $* 881$ & $* 1.0 \%$ & $* 2.9$ & $* 1.5 \%$ & $\wedge 73.8$ & $\wedge 2.1 \%$ \\
\hline Other Asia Pacific & 13.6 & $0.7 \%$ & 2274 & $2.5 \%$ & 5.8 & $3.1 \%$ & 276.5 & $7.7 \%$ \\
\hline Total Asia Pacific & 48.4 & $2.8 \%$ & 8010 & $8.7 \%$ & 17.5 & $9.4 \%$ & 579.9 & $16.3 \%$ \\
\hline Total World & 1706.7 & $100.0 \%$ & 92150 & $100.0 \%$ & 186.6 & $100.0 \%$ & 3551.6 & $100.0 \%$ \\
\hline
\end{tabular}




\subsubsection{Oil and Gas Industry Operations}

Industry operations encompass processing, distribution, servicing, and support of entire production process of a product or service. Core operations of the oil and gas industry include the exploration and production, processing and refining into useable fuels and other valuable commodities, and the transportation from wells to refineries to retail outlets. The oil and gas industry operations are typically split into three main areas; upstream (or exploration and production), midstream

(transportation) and downstream (refining and retailing) [23].

- The Upstream Operations: Includes exploration for potential crude oil and natural gas fields, boring exploratory wells, and afterwards drilling and running the wells that provide and bring the crude oil or raw natural gas to the surface [23].

- The Midstream Operations: Include all activities that have to do with transportation, storage, and wholesale marketing of crude or refined petroleum products. This includes pipelines, barges, trucks, rail and other facilities [23].

- The Downstream Operations: This involves refining, processing and purifying of crude oil and raw natural gas and subsequent marketing and distribution of derived products such as premium motor spirit, kerosene, jet fuel, diesel, lubricants, asphalt, natural gas and liquefied petroleum gas (LPG) as well as other petrochemicals [23].

Based on the categorization above, essentially, the upstream sector focuses of prospecting and extraction of petroleum minerals, the midstream's core operations is transportation through various modes while the downstream focuses on processing or refining of crude oil and gas as well as distribution/marketing of finished products to final consumers. Note that transportation signifies movement of materials between one operational phase to another while distribution describes delivery of processed products to final consumers also known as retailing. Often, the difference between these three sectors gets blurred as they tend to overlap.

\subsection{Climate Change and Oil \& Gas Industry Operations Nexus}

The relationship between oil and gas and the environment has always been contentious. Environmentalists on one hand accentuate the adverse impacts of operations while industry players tend to downplay implied harmful effects. Oil and gas plays a broad and critical role in our society, apart from being a crucial energy source, petroleum products serve as raw materials for many consumer products, thus playing an important role in human lives.

Equally, the oil and gas industry are a source of serious potential risks for the environment impacting it at different levels such as atmosphere, hydrology, pedology and consequently all biotics. Pollution is the most hazardous and widespread outcome of oil and gas industry operations and it is associated with all stages from upstream to downstream. Consequences such as wastewater, emissions of gases, solid waste, crude oil spillages and gas flares generated during drilling, production, refining (attributable to most of the pollution) and transportation constitute more than eight hundred distinctive chemicals, which includes the petroleum products [24].

Generally, attention has always been focused on the impact of oil and gas exploration, production, transportation, processing and marketing activities on the environment. As stated earlier, this is because fossil fuels are perceived as major contributors to global GHG emissions. Therefore, most potential environmental impacts related to oil and gas industry activities are already well documented, however, very little attention has been given to the reverse impact of oil and gas activities, that is, how the attributed contribution to climate change can in turn affect the industry. This is evident in the scanty literature available on the subject matter. It should be noted that oil and gas industry as a major source of climate change inducement - being a major contributor of GHGs - is not 
Contemporary Issues of Climate Change on Oil and Gas Industry Operations

insulated from the reverse effects of climate change. As such, focus shall be on examining how changes in climate can potentially impact the oil and gas industry operations.

\section{Impact of Climate Change on Oil and Gas Industry Operations}

Weather variables, events and systems such as storms, floods, heat waves, strong winds etc. affect various aspects of oil and gas industry, particularly, the operations across various sectors and its infrastructure. Therefore, these operations and infrastructures are already vulnerable to climate related events. Climate change forecast further increases the existing vulnerabilities. Primary research literatures linking weather elements to oil and gas operation are narrow while the few available are in the form of technical reports and working papers. Nevertheless, effort shall be made to pull together all accessible materials in a meaningful way. In the next section, major weather variables, systems and events that are known to impact oil and gas operations and facilities across exploration and production (upstream), transportation (midstream), and refining (downstream) are identified and corresponding impacts are highlighted. Distribution or wholesaling/retailing is outside of the scope of this discussion.

\subsection{Increasing Temperatures}

There has been a persistent rise in global decadal and centennial temperature put approximately at about $1{ }^{\circ} \mathrm{C}$ since 1860 . This has impacted the oil and gas operations and will likely increase in severity based on future forecasts. Higher average temperatures are accompanied by weather events such as increasing heat waves characterized by high humidity and high night time temperatures, increase in occurrence of wildfires, duration and size and thawing of permafrost in the arctic ice sea. These trends are expected to continue. Also, there is spatial disparity in impacts dictated by location of operations and facilities as well degree of exposure. Specific impacts on various operational sectors are presented below.
- Upstream Operations: In the higher latitudes and Polar Regions, thawing permafrost affects the drilling wastes disposal system based on use of sumps that depend on permafrost to avoid movement of wastes at the subsurface into adjoining areas [25]. Increasing temperatures has also been demonstrated to be responsible for loss of access roads to operations facilities built on permafrost. Diminished ice sheet cover restricts ice-based facilities and transportation [26], [27]. Ice cap melting can also increase icebergs, which may be hazardous to oil and gas operations in permafrost regions because increased iceberg movement could disrupt drilling and damage rigs and vessels [28]. Changes in climate may increase the occurrence of polar storms in the future, further interrupting drilling and production [28].

Conversely, warmer temperature could mean a lengthier ice-free season creating a longer exploration, production, and drilling period which may improve rate discovery of new oil and gas fields [25] [26] [28]. Increased temperatures could also unlock additional transportation routes as well and increase the extent of exploration [26] [27]. In the tropics, this could imply lesser use of energy for steaming.

- Midstream Operations: Pipelines buried in ice in Polar Regions, particularly the arctic, will be affected by thawing ice as shown in Figure 1. Load bearing capacities of storage facilities and other infrastructures are reduced [25] [26].

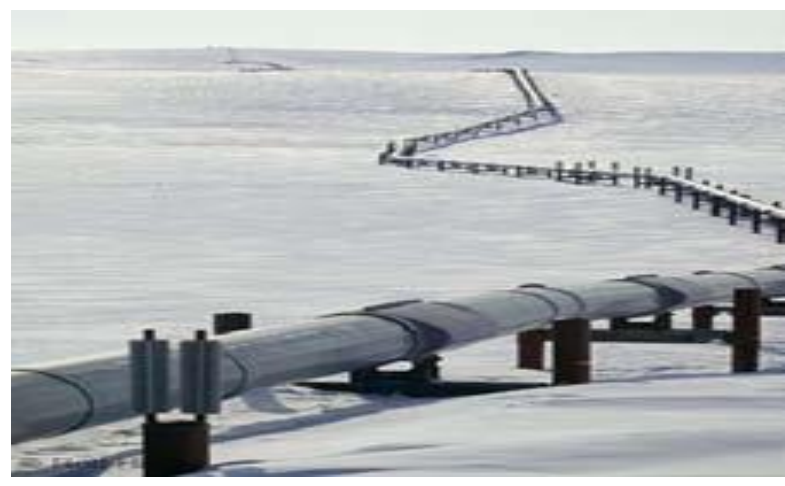

Figure 1: Pipeline in the Arctic [27] 
Oyeleke O. Oyerinde, Int. Ann. Sci.; Vol. 5, Issue 1, pp: 33-46, 2018

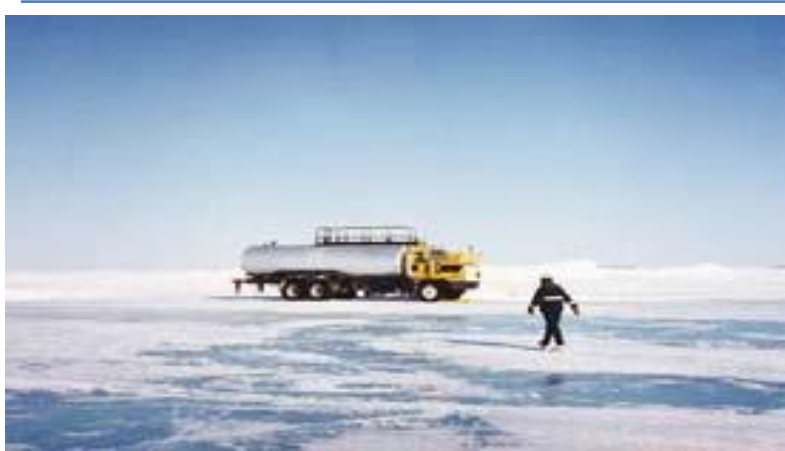

Figure 2: Oil Tanker on Permafrost [29]

Figure 2 shows oil tanker on permafrost, thawing of ice in the region would limit accessibility of these vehicles. Increasing bush fires in warm climates may ignite surface oil and gas pipelines or cause and explosion where there is leakage or corrosion particularly gas pipelines.

- Downstream Operations: Higher energy demand for cooling in natural gas liquefying plants as it is required to be chilled to less than $-160^{\circ} \mathrm{C}$ for efficient transportation. Also, any rise in the severity or occurrence of extreme temperatures will affect the capacity of processing equipment to function efficiently.

In Nigeria, major impact of increased mean temperatures will likely be on the surface pipelines that crisscross the hinterlands supplying crude to refineries and depots as well as the NLNG plant located in Bonny Island, Rivers Sate.

\subsection{Increasing Flooding}

Warmer climate brings heavier rainfall events because warmer air can hold more water [30]. Usually water holding capacity of the air increases by $7 \%$ by every $1^{\circ} \mathrm{C}$ increase in temperature [31]. Increase in rainfall will therefore most likely bring more intense flooding which poses great risk to oil and gas operations.

- Upstream Operations: In the event of flooding, access to onshore well sites is restricted, this limits the efficiency of the fields and reduces any drilling operation during in the period. Excessive flooding has also been attributed to delays in construction of infrastructures on fields and wells as well as their decommissioning. Figure 3 shows a flooded wellhead, drilling rig, crude oil tank, toxic waste water tank lifted from ground, separator and combustor flares submerged under flood waters in Colorado. Flooding is also responsible for numerous disruptions of operations sometimes leading to total shutdowns [32].

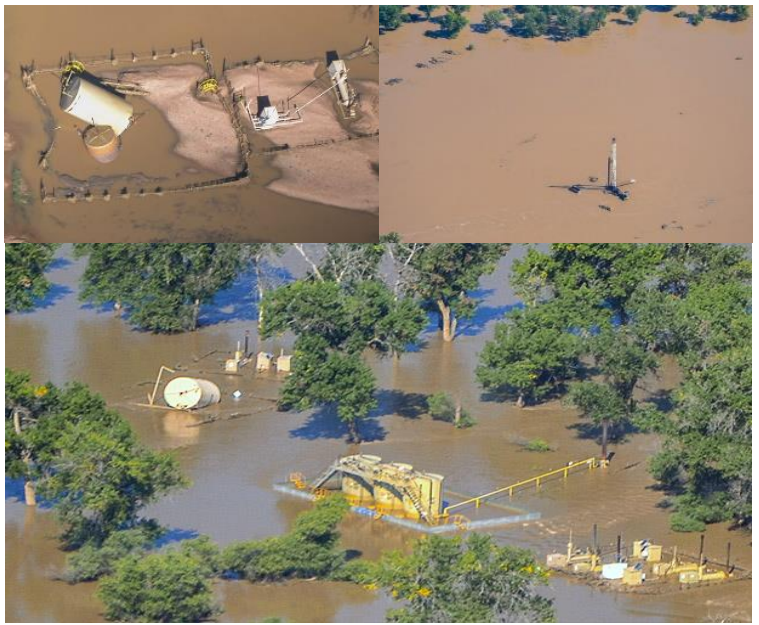

Figure 3: Inundated wellhead and drilling rig in Colorado (EcoFlight)

- Midstream Operations: Floods inflict damages on terminals such as ports, jetties etc. while storage facilities are also not left out. Surface pipelines are inundated and are at times damaged. Flood can trigger landslides and subsidence thereby posing great risk to underground pipelines [33] [34]. Also, it is common for floating tank roofs to sink or tip, uncovering tanks tops, susceptible to fires in case of lighting.

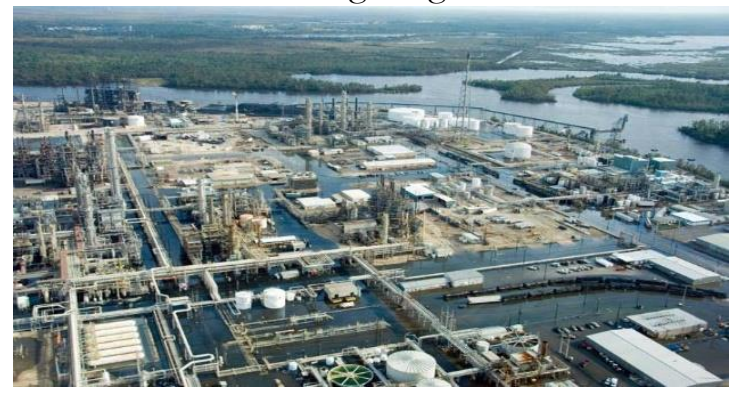

Figure 4: Flooded Refinery in Texas [35]

- Downstream Operations: Flooding of refineries and related petrochemical plants is quite common. Figure 4 shows a flooded refinery in Texas, USA [35]. 
This of course, causes severe damages to such facilities and equipment therein. Processing activities are usually disrupted which sometimes creates supply shortages, revenue loss and attendant price increases.

Based on latest global projections, the heaviest precipitation is likely to manifest twofold as often as they do presently by the end of 21 st century [36]. Consequently, variations in the timing and quantity of rainfall may alter occurrence, intensity and length of flood [37]. Essentially, floods inflict a lot of damage on operations assets causing serious disruptions resulting to significant losses in terms of manpower, time and money. Apart from this, it poses great danger to the human resources and cases of injuries and fatalities have been reported [32]. In Nigeria, floods have been on an increasing trend. Although rainfall is decreasing in the northern region, it is however on the rise the southern coasts [7] where more than $90 \%$ of the oil and gas industrial operations and installations are located. Increasing flood events will no doubt impact activities and infrastructures located in the southern region.

\subsection{Storm Surges, Sea Level Rise and Coastal Erosion}

The severity of tropical storms has increased since 1970s [5] and still likely to increase in the foreseeable future. Some studies suggest that it is likely that fewer storms will occur, but those that do occur will likely be stronger somewhere in the range of category 4 or 5 [5].

There was a rise in global absolute sea level at $1.8 \mathrm{~mm}$ per annum between 1880 and 2011. This rose to between $2.8-3.3 \mathrm{~mm}$ annually from 1993 to 2011 [38]. Presently, the rate of rise has doubled compared to last century owing to increased melting of glacier and ocean thermal expansion from rising temperature [39] [40].

Estimates from recent studies project sea level rise by 2100 using 1992 as base year as 0.3 to 1.2 meters plausibly which will of course differ across locations when considered along with subsidence and relative sea level rise [40] [41].

- Upstream Operations: Storm surges and sea level rise cause damage to drilling and production platforms. For instance, figures 5 and 6 shows the outcome of storm events recoded in the United States in 2005 dubbed Hurricane Katrina and Rita that damaged more than hundred oil and gas drilling platforms [40] [42]. Large accompanying waves disrupt mooring of drilling platforms [33]. Cyclones cause delays in platforms construction and decommissioning [32].

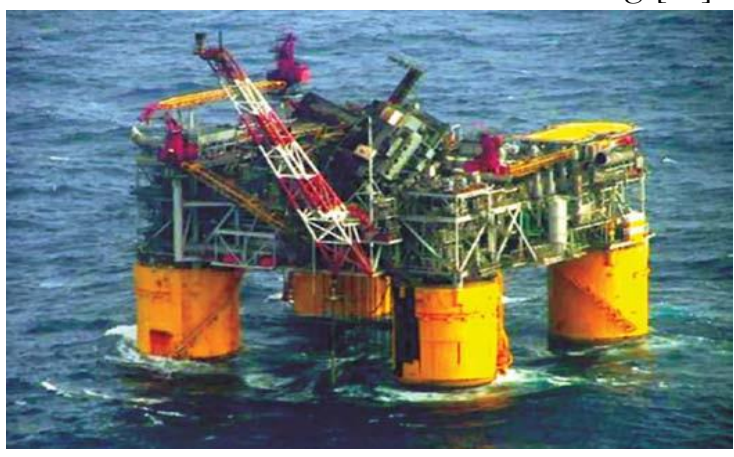

Figure 5: Damaged Offshore Platform after Hurricane Katrina [43]

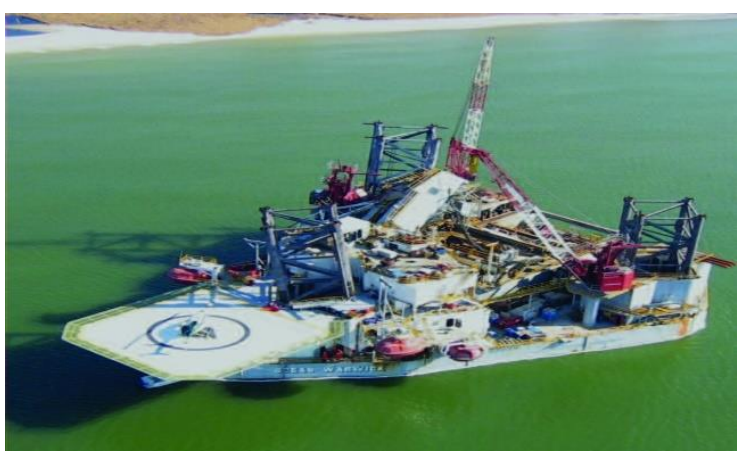

Figure 6: Damaged Offshore Platform [34]

- Midstream Operations: Studies show that offshore pipelines are greatly impacted by storm surges and sea level rise. E.g. Hurricane Katrina and Rita damaged about 457 offshore oil and gas pipelines in the US [26]. This will also have temporary impacts on ports operation for vessels. Coastal erosion exposes underground pipelines and may damage surface pipelines [33].

- Downstream Operations: Coastal processing plants are mostly affected by being inundated and rendered inoperative [34]. Figure 7 shows one of the nine refineries that were shut down for six months in the case of hurricane Katrina in US in 1995 resulting in total 
Oyeleke O. Oyerinde, Int. Ann. Sci.; Vol. 5, Issue 1, pp: 33-46, 2018

shut down of oil production in the Gulf of Mexico cutting annual production by $20 \%$ [32].

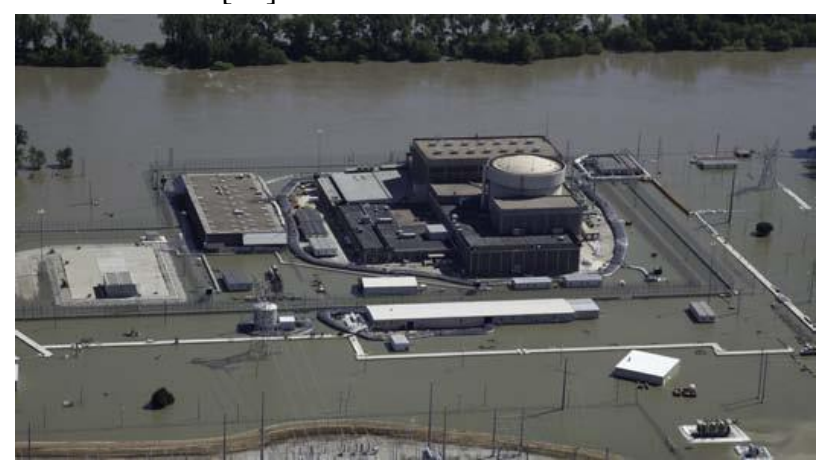

Figure 7: Submerged Refinery [44]

In coastal areas, storm events along with rise in sea level will add to more profound storm surge effects. This will also increase the storm intensity and rise in sea level over time [45]. Rise in sea level increases current vulnerabilities to storm surge since storms destroy wetlands and other natural and anthropogenic attributes that help safeguard coastal facilities from sea level rise, flooding, and storms [40].

With increasing severity and frequency of these extreme events, most of the oil and gas operations and facilities in Nigeria will become threatened since an overwhelming majority is located onshore and offshore of coastal cities mostly below 10 meters above seal level. This will no doubt have far reaching implications for the oil and gas firms in terms of reduced revenue as well as the government since royalties from this sector account for more than $65 \%$ of national budgetary revenue. Consumers may face acute temporary shortages and increased price.

\subsection{Drought and Water Shortage}

Naturally arid locations are disposed to drought because they depend on little rainfall to provide moisture annually. Future upsurges in temperature and consequently evaporation implies that many areas will become drier in the coming years, particularly at higher emissions scenario [40]. Currently, due to the increase in temperature and evaporation, dry land has increased from $15 \%$ to $25 \%$ of the global total land area [46] [47]. It is a well-known fact that oil and gas industry operations are water intensive. It is therefore vulnerable to decline in water availability to sustain operations.

- Upstream Operations: Water is a major constituent used for crude oil recovery. Steaming is extensively used for drilling unconventional and heavy oils. Drought will no doubt impact onshore shale oil and gas exploration greatly.

- Midstream Operations: Dry conditions could significantly increase risk of bushfire occurrence which could subject surface pipelines to ignition. Increasing aridity or dryness also exposes buried facilities to wind driven erosion, as such, underground pipelines may become exposed and, in some cases, damaged.

- Downstream Operations: Oil refineries and gas plants make use of a lot of water during processing. It is estimated that refineries uses about 2.5 liters of water for every one liter of production unit [32]. Water shortage condition will likely impact processing operations in the arid regions which may disrupt and/or decrease productivity and output level.

As stated under impact of increasing flooding events, droughts, that is decreasing precipitation and moisture availability being experienced in the north has led to rapidly expanding semi-arid and arid zones in Nigeria [17] [18]. Water shortage has the potential to stimulate development of water efficient technologies for oil and gas industrial operations. This water shortage condition will likely impact oil and gas operations in the northern region, particularly, the Kaduna refinery and its pipeline network. Dry conditions may lead to greater competition between oil and gas and other activities such as mining, manufacturing, farming, towns and cities for water resources.

\subsection{Wind and Waves}

As climate change intensifies, stronger winds and wind gusts will likely be experienced [48], 
[49]. These will certainly impact oil and gas operations.

- Upstream Operations: Extreme winds have led to evacuation of platforms due to wind and wave loading [33]. This is capable of destroying platforms particularly offshore infrastructures.

- Midstream Operations: Extreme winds prevent docking of vessels, damage pipelines and connections between processing and storage units. It also damages pipelines by dislocation of risers or host platform [33], [34]. Strong surface winds and currents can create substantial underwater forces capable of damaging offshore pipelines.

- Downstream Operations: Toppling of processing units has been attributed to violent winds as well as dislodging of refinery roofs and equipment [34].

Wind is also known to inflict damages on infrastructure from projectiles such as tree branches, signs and roof tops [34]. On the other hand, stronger wind could points to potential source of energy to support operations. Impact of wind will be most felt on offshore installations in Nigeria and those located in the northern regions. As pointed out earlier, strong winds in arid regions could expose underground pipelines in such area besides damages to other facilities like the refinery. Also, winds exacerbate cases of bushfires thereby increasing severity, size and rate of spread.

\subsection{Subsidence, Landslides and Mudslides}

Increasing droughts and saturated grounds is expected to increase occurrences of subsidence and landslides [33].

- Upstream Operations: Subsea mudslides, induced by dislocation of shallow water regions can damage platforms [34].

- Midstream Operations: Impact will be felt in subsurface operations especially buried infrastructures like underground pipelines and storage depots.
- Downstream Operations: Refineries located along the coast will likely experience damages similar to the upstream and midstream sectors.

Generally, impacts of subsidence, landslides and mudslide are relatively less widespread compared to other previously discussed events. Based on climate change projections, frequency of occurrence is expected to increase in Nigeria. Areas that will be most impacted are the offshore and coastal operations in the Niger Delta region.

\section{Adaptation}

It is gradually becoming clearer that present regulatory structure and benchmarks are not enough to shield company assets and activities from severe weather events. Besides, before now, the industry top players have not taken climate change adaptation as priority [32]. Adaptation is concerned with taking practical actions to manage risks from climate impacts, to protect oil and gas industry operations and infrastructures and to strengthen the resilience of the sector. As such it involves taking steps to reduce the vulnerability of operations and assets to current climate system [50]. Adaptation is especially important in developing countries like Nigeria since they are predicted to bear the brunt of the effects of global warming because of their low level of technology and widespread poverty. Some adaptation measures that have been successfully applied or can be deployed to address weather event identified are examined below.

\subsection{Increasing Temperatures}

Use of more efficient chillers and cooling units are advocated in gas plants [51]. Adoption of retrofits and structural upgrades to facilities is being implemented.

\subsection{Increasing Flooding}

Infrastructures are being located and positioned taking into cognizance possible occurrence of flooding. Barriers in form of strong walls are being constructed to shield facilities from flood. Improved drainage 
Oyeleke O. Oyerinde, Int. Ann. Sci.; Vol. 5, Issue 1, pp: 33-46, 2018

systems are being designed for onshore platforms [51].

\subsection{Storm Surges, Sea Level Rise and Coastal Erosion}

Companies are investing in more robust offshore rig and well equipment to be able to withstand storms and inundation. Retrofit oil and gas offshore platform that can withstand violent storms e.g. category 5 cyclones. Coastal erosion management strategies are gradually being incorporated into infrastructure designs. IPCC encourages construction of levees and seawalls in coastal areas to protect infrastructures [32].

\subsection{Drought and Water Shortage}

Recently, as a response to climate risk per availability of water, there has been a renewed drive for water efficiency in oil and gas industry operations. It is on record that British Petroleum was able to reduce water usage by 80 percent, Shell petroleum in some place 100 percent. This was achieved by reduction in consumption and a near complete shift to use of wastewater for virtually all water required operations. This has helped conserve water, reduced cost of operation and increased profitability. There is increasing harvesting of produced waters such as storm and flood waters for usage and aquifer recharge [52], [53].

\subsection{Wind and Waves}

Clamps failure as a result of extreme winds is being addressed through strengthening of recently constructed clamps. For instance, Shell's redesigned clamp after hurricane Katrina incident is four-fold stronger than before [54].

\subsection{Subsidence, Landslides and Mudslides}

Possible shallow water area displacements and subsidence are strongly considered in determining location of offshore and buried assets. Structural upgrades to infrastructure are also being considered.

\section{Mitigation}

This comprises of interventions or policies to reduce the emissions or enhance the sink of greenhouse gases that have been identified as primary inducers of rapidly changing climate. Since sources of GHGs transcend oil and gas operations, effective mitigation policy is that which is holistic capable of capturing all sources such as land use, agriculture, urbanization, electricity generation etc. as well as interdependencies. For the purpose of this discussion, focus shall be on mitigative measure applicable to oil and gas industry operations.

\subsection{Increased Extraction and Production Efficiency}

The oil and gas sector has channeled substantial investment into improving extraction and production efficiency since the 1990s which marks a period of increased energy intensity propelled by need to drill deeper and further offshore to discover and produce oil and gas, improve technology for oil and gas recovery, exploit heavy oils and hitherto inaccessible reservoirs. By 2007, significant achievements have been recorded in this regard as efficiency improved substantially above 1990s levels [50]. For example, in 2000, ExxonMobil initiated Global Energy Management System (GEMS) which helped increase energy efficiency by 15 to 20 percent, saving around US\$750 million aside from the close to 8 million tonnes of $\mathrm{CO}_{2}$ emission that was cut down [32].

\subsection{Improved Refining and Processing Efficiency}

Increased demand for refined petroleum products have increased use of energy intensive methods such as desulphurization in order to reduce environmental impact. There are reports that many oil and gas firms are now adopting efficiency measure such as combustion optimization, control of compressed air and steam leaks and utilization of efficient electrical appliances among others. Between 3\% to 35\% reductions in energy use have been reported [55].

\subsection{Reduction of Gas Flaring and Venting}

Gas is flared or vented sometimes as a safety measure and at times when there is no local market and/or requisite facility to offtake natural gas. Technologies such as flash gas compressors 
convert gas that would have been flared into a resource. This help eliminate or at least reduces flaring and venting and at the same time turning waste into valuable resource which also increases revenue. Several oil and gas firms around the world report decreasing gas flaring by up to $80 \%$ in their oil and gas fields [56]. It is concerning that many developing countries still flare and vent natural gas. In this category is Nigeria, despite several policies, laws and regulation. Notwithstanding, the country has shown a gradual but sustained decline in gas flaring from $51.49 \%$ flared in 2001 to $11.2 \%$ in 2015 . It is believed that the new Petroleum Industry Governance Bill in progress will address most of the challenges.

\subsection{Carbon Capture and Storage}

Carbon capture and storage (CCS) has become popular in the oil and gas sector. It involves sequestration of carbon both at the upstream and downstream sectors. Carbon is captured and reinjected into geological formations and it is also harvested directly during refining. These methods have been proven to be economically viable over the years. For instance, 1 million krone (Norwegian currency) is being saved per day by Norwegian Sleipner gas field from decreased national carbon tariffs [32].

\subsection{Stoppage of Fugitive Emissions}

Almost imperceptible emission of methane must be addressed as it is known to have greater heat absorbing capacity compared to carbon and also stays longer in the environment. Currently, economically feasible technologies are being developed to cut fugitive emissions by as much as $80 \%$ which should become available soon [32].

\subsection{Investing in Alternative Technologies}

It is interesting to note that oil firms are at forefront of research and development in alternative or renewable energy technologies such as solar, wind, geothermal, biofuels, battery and co-generation among others. Billions of dollars have been invested by oil and gas firms in this effort such that low carbon energy markets are now among the fastest growing globally specifically since 2008 [57]. Presently, annual global investments in renewable energy far outstrip that of petroleum fuel. Moreover, many countries have now set deadlines to end use of fossil fuel providing further impetus towards divesting to cleaner energy technologies.

\section{Conclusion}

Relationship between various climate variables and different aspects of oil and gas industry operations is irrefutable. Also, potential impacts of anticipated changes in climatic conditions in the future are very real. Current climate models point to increasing climate change which points to exacerbation of attendant impacts regardless of mitigation efforts because of the existing momentum. Unfortunately, there is no full understanding on how exactly these changes would impact oil and gas operations unlike those of other energy sectors especially electricity that have recorded a lot of research efforts involving use of physical and economic models to explains current impact and to predicts future effects though not without some challenges. Nonetheless, it is certain from information gleaned from very few and disparate works in the form of institution reports, technical papers, conference proceedings and other evidences available that oil and gas sector is not immune to climate change impact. This no doubt provides a useful guide at least on an interim basis. There is however urgent need to develop empirical models that clearly explains link between changes in climate and impact on oil and gas operations with built in capacity to predict future impacts accurately.

\section{How to Cite this Article:}

O. Oyerinde, "Contemporary Issues of Climate Change on Oil and Gas Industry Operations", Int. Ann. Sci., vol. 5, no. 1, pp. 33-46, Jun. 2018. doi: 10.21467/ias.5.1.33-46

\section{References}

[1] World Energy Council. "Climate Change: Implications for the Energy Sector." Key Findings from the Intergovernmental Panel on Climate Change Fifth Assessment Report. 2014.

[2] International Institute for Applied Systems Analysis. Progress Report to IIASA's National Member Organizations and Governing Council on IIASA's Research and Other Activities in 2010. 
Oyeleke O. Oyerinde, Int. Ann. Sci.; Vol. 5, Issue 1, pp: 33-46, 2018

[3] Intergovernmental Panel on Climate Change. Climate change assessments Review of the processes and procedures of the IPCC. 2010.

[4] P.A. O'Connor. "Energy Transitions". The Pardee Papers. Number 12. Boston University. 2010.

[5] Intergovernmental Panel on Climate (IPCC). Climate Change 2007. The Fourth Assessment Report (AR4). "Synthesis report for policymakers". 2007.

[6] United Nations Framework Convention on Climate Change (1992). United Nations. New York. https://unfccc.int/resource/docs/convkp/conveng.pdf

[7] P.A.O. Odjugo. "Climate Change and Global Warming: The Nigerian Perspective" Journal of Sustainable Development and Environmental Protection Vol. (1) No. (1). 2011.

[8] J.O. Ayoade. Climate Change. Ibadan. Vantage Publishers. Pp45-66. 2003.

[9] M.I. Rahman. "Climate Change: A Theoretical Review". Interdisciplinary Description of Complex Systems 11(1), 1-13. 2013.

[10] National Aeronautics and Space Administration. Climate Change: How do we know? 2012. http://climate.nasa.gov/evidence

[11] J.L. Blast. Seven Theories of Climate Change. The Heartland Institute. Chicago, Illinois. ISBN-13 9781-934791-31-8. 2010.

[12] U. Harshita. "Theories of Climate Change". International Journal of Geology, Earth \& Environmental Sciences Vol.3 (3) SeptemberDecember, pp.9-10. December 2013.

[13] Department of Economic Development (DED). Division of Energy. Missouri. https://energy.mo.gov/energy/stay-

informed/publications-reports/global-climate-

change-effect-of-the-earth\%27s-orbit Accessed: 22nd March 2018.

[14] P.A.O. Odjugo. "General Overview of Climate Change Impacts in Nigeria". Journal of Human Ecology, 29(1): 47-55. 2010.

[15] United States Environment Protection Agency. Climate Change Indicators in the United States. Fourth Edition. 2016.

[16] Intergovernmental Panel on Climate (IPCC). Climate Change 2014. The Fifth Assessment Report (AR5). "Synthesis Report". 2014.

[17] P.A.O. Odjugo and A.I. Ikhuoria. "The Impact of Climate Change and Anthropogenic Factors on Desertification in the Semi-Arid Region of Nigeria". Global Journal of Environmental Science, 2(2):118126. 2003.

[18] T.E. Olagunju. "Drought, Desertification and the Nigerian Environment: A Review". Journal of Ecology and the Natural Environment. Vol. 7(7), pp. 196-209. 2015.

[19] British Petroleum Statistical Review of World Energy. 66 $6^{\text {th }}$ Edition. 2017.

[20] ENI World Oil and Gas Review. 2016. https://www.eni.com/docs/en_IT/enicom/company/fu el-cafe/WOGR-2016.pdf

[21] The African Development Bank Group. "Crude Oil and Natural Gas Production in Africa and the Global Market Situation". Commodities Brief. Volume 1, issue 48. 2010.

[22] Department of Petroleum Resources (DPR). Oil and Gas Annual Report. 2016.
[23] Petroleum Services Association of Canada (PSAC). http://www.psac.ca/business/industry-overview/ Accessed: 23rd March 2018.

[24] J.B. Mariano and E.L. La Rovere. "Environmental impacts of the oil industry". Petroleum engineeringDownstream, Encyclopedia of Life Support Systems (EOLSS).

[25] Alaska Department of Environmental Conservation. Alaska's Climate Change Strategy: Addressing Impacts in Alaska. Final report submitted by the Adaptation Advisory Group to the Alaska Climate Change Sub-Cabinet. 2010.

[26] V. Burkett. "Global Climate Change Implications for Coastal and Offshore Oil and Gas Development." Energy Policy 39 (12): 7719-25. 2011.

[27] Society of Petroleum Engineers. "Adaptation in the Oil and Gas Industry to Projected Impacts of Climate Change." Presented at the SPE International Conference on Health, Safety and Environment in Oil and Gas Exploration and Production, Rio de Janeiro, Brazil. 2010.

[28] O.A. Harsem, A. Eide, and K. Heen. "Factors Influencing Future Oil and Gas Prospects in the Arctic." Energy Policy 39(12): 8037-45. 2011.

[29] NETL. "Physical, Biological, and Chemical Implications of Midwinter Pumping of Tundra Ponds." National Energy Technology Laboratory.

[30] S.K. Min, X. Zhang, F.W. Zwiers, and G.C. Hegerl. "Human contribution to more-intense precipitation extremes". Nature, 470: 378-381. 2011.

[31] K. Trenberth. "Changes in Precipitation with Climate Change." Climate Research 47: 123-138.

[32] Investor Group on Climate Change (IGCC). Assessing Climate Change Risks and Opportunities for Investors. Australian National University. 2014.

[33] E.A. Byers and J.M. Amezaga. "A Climate Change Report Card for Infrastructure. Energy: Nuclear, Coal, Oil and Gas". Working Technical Paper. 2015.

[34] National Wildlife Federation (NWF). More extreme Weather and The US Energy Infrastructure. 2011.

[35] Public Broadcasting Service (PBS). "Flooded Refinery." Photo shared through PBS NewsHour photostream on flickr. http://www.flickr.com/photos/newshour/2866893962 I. Accessed: March 20th 2018.

[36] V.V. Kharin, F.W. Zwiers, X. Zhang and M. Wehrner. "Changes in Temperature and Precipitation Extremes in then CMIP5 Ensemble." Climatic Change 119: 345-357. 2013

[37] R.M. Hirsch and K.R. Ryberg. "Has the Magnitude of Floods Across the USA Changed with Global $\mathrm{CO} 2$ Levels?" Hydrological Sciences Journal 57: 1-9. 2012.

[38] U.S. Environmental Protection Agency (EPA). Climate Change Indicators in the United States. Washington, DC.

[39] J.A. Church and N.J. White. "Sea-level rise from the late 19th to the early 21st century." Surveys in Geophysics 32, 585602. September 2011.

[40] United States Department of Energy. US Energy Sector Vulnerabilities to Climate Change and Extreme Weather. DOE/PI-0013. 2013.

[41] NOAA. "Global Sea Level Rise Scenarios for the United States National Climate Assessment". Parris. National Oceanic and Atmospheric Administration Tech Memo OAR CPO-1. December 2012. 
[42] International Energy Agency. Making the Energy Sector More Resilient to Climate Change. 2015.

[43] United States Climate Change Science Program (CCSP). "Effects of climate change on energy production and distribution in the United States." In: Effects of Climate Change on Energy Production and Use in the United States, Synthesis and Assessment Product 4.5, 8-44. Washington, DC: U.S. Climate Change Science Program. 2008.

[44] Nebraska Power Association (NPA). "Missouri River Flooding of 2011."

[45] B.H. Strauss, R. Ziemlinski, J.L. Weiss and J.T. Overpeck. "Tidally adjusted estimates of topographic vulnerability to sea level rise and flooding for the contiguous United States." Environmental Research Letters, 7. 2012.

[46] C.M. Johanson and Q. Fu. "Hadley Cell Widening: Model Simulations versus Observations". Journal of Climate, 22: 2,713-2,725. 2009.

[47] A. Dai. "Drought under global warming: a review". WIREs Climate Change, 2(1): 45-65. October 2010.

[48] S. Eichelberger, J. Mccaa, B. Nijssen and A. Wood. "Climate Change Effects on Wind Speed". North American Windpower. 2008.

Publish your research article in AIJR journals$\checkmark$ Online Submission and Tracking

$\checkmark$ Peer-Reviewed

$\checkmark$ Rapid decision

$\checkmark$ Immediate Publication after acceptance

$\checkmark$ Articles freely available online

$\checkmark \quad$ Retain full copyright of your article.

Submit your article at journals.aijr.in
[49] C.S. Cheng, E. Lopes, C. Fu and Z. Huang. "Possible Impacts of Climate Change on Wind Gusts under Downscaled Future Climate Conditions: Updated for Canada”. Journal of Climate. Vol. 27. Pp 1-16. 2014.

[50] IPIECA. Energy Efficiency: Improving Energy Use from Production to Consumer. 2012.

[51] Acclimatise. 'Understanding the investment implications of adapting to climate change - oil and gas'. Oxford. October 2009.

[52] M. Smith. Water Efficiency Opportunities - Best Practice Guide - Petroleum Refining. DSEWPC, ANU FSES. 2010.

[53] Shell. Climate Change Adaptation: Evaluating the vulnerability of assets to climate change IPIECA workshop Addressing Adaptation in the Oil and Gas Industry. 2013.

[54] British Petroleum Australia. BP-Bulwer Island Refinery. BP Australia. September 2009.

[55] E. Worrell. Energy Efficiency Savings in the Petroleum Refining. US EPA and the LBNL. 2005. DOI: $10.2172 / 862119$

[56] IEA Conventional Oil and Gas Technologies. IEA. 2010.

[57] T. Edis. AGL and Infigen's view of the future. Climate Spectator. 2012.

Publish your books with AIJR publisher-

$\checkmark \quad$ Publish with ISBN and DOI.

$\checkmark$ Publish Thesis/Dissertation as Monograph.

$\checkmark$ Publish Book Monograph.

$\checkmark$ Publish Edited Volume/ Book.

$\checkmark$ Publish Conference Proceedings

$\checkmark \quad$ Retain full copyright of your books.

Submit your manuscript at books.aijr.org 